\title{
INTERNATIONAL TOURISM: MODERN TRENDS, MODELS AND PROCESSES
}

\author{
Roberto Paolo Vico ${ }^{1}$
}

\begin{abstract}
In a world and travel universe subject to continuous change, the tourism phenomenon is under ever greater pressure to evolve and respond to the world it inhabits - in order to survive. The object of the paper is to discuss and analyze, some of the important issues and trends relating to tourism phenomenon. In particular, ways in which the tourism and its consumers are being affected and affecting these trends. The first two sections deploy elements of a steep analysis in order to detect significant demographic and macro political forces affecting tourism phenomenon. Section three considers the "day-to-day...sphere" of travel and tourism, its 'microenvironment', the competition and markets forces they encounter there. The paper reviews one of the most significant micro trends affecting the airline sector: the dynamic growth of low cost carriers. The last part of this work looks into strategic and analytic models associated with tourism, highlighting some of the strategic directional trends being adapted to tourism sectors and into new collaborative forms of social media, communications and marketing.
\end{abstract}

Keywords: tourism, macro/micro trends, development models.

\section{TURISMO INTERNACIONAL: TENDÊNCIAS MODERNAS, MODELOS E PROCESSOS}

\section{Resumo}

Em um mundo e universo de viagens sujeitos a mudanças contínuas, o fenômeno do turismo está sob pressão cada vez maior para evoluir e responder a estas transformações. O objetivo do artigo é discutir e analisar algumas das questões e tendências importantes relacionadas ao fenômeno do turismo. Em particular, maneiras pelas quais o turismo e seus consumidores estão sendo afetados e afetam essas tendências. As duas primeiras seções abordam elementos de uma steep análise acentuada para detectar importantes forças demográficas e macropolíticas que afetam o fenômeno do turismo. A seção três considera a "esfera do dia-a-dia ... " de viagens e turismo, seu "microambiente", a competição e as forças de mercado que se encontram. O artigo analisa uma das micro-tendências mais significativas que afetam o setor aéreo: o crescimento dinâmico das operadoras de baixo custo. A última parte deste trabalho aborda os modelos estratégicos e analíticos associados ao turismo, destacando algumas das tendências direcionais estratégicas sendo adaptadas para o setor do turismo e às novas formas colaborativas das redes sociais, comunicação e marketing.

Palavras-chave: turismo, macro / micro tendências, modelos de desenvolvimento.

\footnotetext{
${ }^{1} \mathrm{PhD}$ Student at University of Valenciennes et Hainaut-Cambresis (UVHC) belonging at Doctoral School in Human and Social Science of University of Lille3 (France) in co-mentoring with Federal University of Rio Grande do Norte (UFRG), Natal, Brazil. Assistant Professor at Inhambane Higher Institute for Tourism and Hotel Studies (ESHTI), Universidade Eduardo Mondlane (UEM) - Inhambane, Mozambique. E-mail: robertofigo@hotmail.com.
} 


\section{TURISMO INTERNACIONAL: TENDENCIAS MODERNAS, MODELOS Y PROCESSOS}

\section{Resumen}

En un universo mundial y de viajes sujeto a continuos cambios, el fenómeno del turismo está bajo una presión cada vez mayor para evolucionar y responder al mundo en el que habita, para poder sobrevivir. El objetivo del documento es discutir y analizar algunos de los temas y tendencias importantes relacionados con el fenómeno turístico. En particular, las formas en que el turismo y sus consumidores se ven afectados y afectan estas tendencias. Las dos primeras secciones despliegan elementos de un análisis profundo para detectar importantes fuerzas demográficas y macro-políticas que afectan el turismo. La tercera sección considera la "esfera del día a día" de los viajes y el turismo, su "microambiente", la competición y las fuerzas de los mercados que encuentran allí. El documento revisa una de las micro-tendencias más importantes que afectan al sector de las aerolíneas: el crecimiento dinámico de las aerolíneas de bajo costo. La última parte de este trabajo analiza los modelos estratégicos y analíticos asociados con el turismo, destacando algunas de las tendencias direccionales estratégicas que se están adaptando a los sectores del turismo y a las nuevas formas colaborativas de las redes sociales, las comunicaciones y el marketing.

Palabras-clave: turismo, macro / micro tendencias, modelos de desarrollo.

\section{INTRODUCTION}

Changing demographic trends are one of the key external factors continuing to shape travel related industries. Forecasts suggest a rise from around 7 billion to around 8.3 billion people in 2030. In particular Asia and the Americas seem set to rise strongly, $18 \%$ and $17 \%$ respectively between 2009 and 2030. Although the distribution of the global population will remain largely static in proportional terms, growth will be unevenly distributed (World Tourism Organization, 2010).

In the first section this paper looks at some key demographic trends set to reconfigure the global tourism map. Arguably, one of the most important politico-economic trends influencing international tourism has been, the super trend towards international regulatory liberalization and deregulation. In order to gain insight into recent trends in the critical air transportation sector a macro political analysis is adopted. This macro political environment can be said to include governmental, legal and regulatory influences as well as other areas under the direct/ indirect power, control or influence of governmental authorities. After the EU's eastern enlargement in 2004 there was no fewer than 20 low cost carriers (LCCs), offering 'cheap tickets' via "short and middle-haul" routes - connecting continental cities (GABOR, 2010, p.53). Between the EU expansion and implementation of the "Single 
European Sky' between 2004 and 2009, the market supply of LCCs experienced a trend of dynamic expansion, as indeed did, their geographical distribution, becoming much "more diverse" (GABOR, 2010, p. 53). Through using a network analysis technique, the intentions below is to discern some of operative trends within this critical micro sphere of the tourism business. At the business development level a number of trends can also be observed in relation to the strategic options being deployed by travel operators.

This paper looks firstly at some of the more general theoretical trends informing managers' strategic decisions. Models which take into account factors from, core competences, to the risk continuum, market penetration, product development and a variety of forms of dynamic diversification. The manner in which these consideration have been apply will then be considered in order to better understand why tourism companies chose different models and strategic directions. While internal development remains important for many companies in travel related industries (e.g. airlines, hotels), they are increasingly integrating 'collaborative models' into their strategic plans. A major shift in international business and the tourism sector, has arguably been the trend from competitive to collaborative business strategies. Perhaps none more so that 'strategic alliances', between companies in both complementary and competing sectors. Consideration is given to the permanency of this trend. As mentioned above, some of the changes in the tourism has been the trend towards increased use of collaborative system models, but equally important is the integration of new digital technologies in the value chain and marketing processes.

The final section concludes with a look at these new trends as they relates to customer behavior, taste formation and product design. Highlighting various important conceptual trends affecting both marketing departments, but also consumers' themselves - embedded in social networks.

\section{TOURISM MACRO TREND (A) - SOCIAL}

\section{Growing and ageing populations}

Macro meaning the "broad environment outside of an organization's industry" (EVANS et al., 2003, p.156). Perhaps one of the most significant factors will be the interrelated global shifts in life expectancy/fertility, in conjunction with an ageing global population trend (e.g. Western Europe, North America, Japan, and Russia). Not only is there a growth in older tourists, but they will increasingly live longer, retain higher than average 
levels of disposable income, while being healthy and "younger looking in outlook" (WORLD TOURISM ORGANIZATION AND EUROPEAN TRAVEL COMMISSION, 2010, p.4) $)^{2}$. While continued population growth presents great opportunities for the tourism business, generating a significant expansion in out of country travel, other demographic changes look set to present significant challenges, impacting not only upon the kind of tourists travelling, but their domiciled departure location, the places they visit, the kind of lodgings they desire, as well as, the type of activities they engage in whilst travelling.

\section{Socio-structural changes}

Demographic changes can also be seen in alterations in family structure and household composition, especially in developed nations. Sociologists have described a shift from the 'horizontal' to the 'vertical' family, with many members of the same generation, to a more equal spread across the age groups (WORLD TOURISM ORGANIZATION AND EUROPEAN TRAVEL COMMISSION, 2010). Tourism will be required to adapt itself to offer more creatively packaged and variegated services, catering for example, from single travelers to multi-generational travel parties. While such socio-structural changes present potentially attractive new customer segments. For example, the trend towards changes in 'seasonality' of the traditional vacation markets, with older tourists having more free time accompanied by disposable incomes, and the wish to try new activities and locations.

\section{Population locations}

Another important global trend is that of 'urbanization', and with it the growth of tourism. Mason appropriately notes that "modern tourism developed largely as a result of urbanization in Western Europe" (MASON, 2003, p. 12-13). This trend remains an integrative characteristic in the age of globalization. Indeed, the population of the world is set to continue becoming ever more urbanized in coming decades. The World Tourism Organization (WTO) forecasts that by 2030 Asia itself will "account for $60 \%$ of the world's population", with China closely followed by India each supplying just under 20\% each (WORLD TOURISM ORGANIZATION AND EUROPEAN TRAVEL COMMISSION, 2010, p. 5).

For the first time in human history more than $50 \%$ of the world population now live as urbanites in small to mega cities. If this trend continues in developing societies, particularly

${ }^{2}$ See also Ryan and Trauer (2005). 
nations with large populations and growing economic power, such as China, India, Indonesia and Brazil, the concentration of the global tourism map looks set to change with it. Leaving such nations set to develop into some of "the world's largest producers of international tourists" (WORLD TOURISM ORGANIZATION AND EUROPEAN TRAVEL COMMISSION, p. 2010: 5).

These demographic trends will have important implications for global tourism markets, as the World Tourism organization acknowledges. For example, large numbers of these new Chinese tourists' will be around 16-35, both with aspirations to purchase travel goods and services, as well as the disposable incomes with which to do it (WORLD TOURISM ORGANIZATION AND EUROPEAN TRAVEL COMMISSION, 2010).

\section{TOURISM MACRO TREND (B) - POLITICAL}

\section{Regulation and Liberalization of Air Space}

In this section we continue with a macro analysis of another important trend in business and tourism operations. The macro political environment is usefully delineated as follows: legislation and regulation, economic policy, government-owned businesses (e.g. airlines) and government international policy (EVANS et al., 2003). This environment will also include some element of political risk. Travel and tourism businesses can be particularly prone to adverse financial and reputational outcomes, as a result of socio-political instabilities in international travel business locations (EVANS et al., 2003).

The political environment of international air transportation since the end of the 2nd World War was warily regulated via thousands of bilateral agreements between partner nation governments (BUTTON, 2009 apud GABOR, 2010). Many dating back to the Chicago Convention of 1944 and the Bermuda Agreement of 1946. Founded upon the basic recognition of the "sovereignty of nations over their airspace", and "equal right for every nation to participate in air travel," (five freedoms of the air) (EVANS et al., 2003, p. 166).

These agreements were subsequently followed by a complex maze of bilateral intergovernmental agreements which enabled the government stakeholders involved, the ability to preserve control over their perceived national interests relating to air travel. However, more recently this control has been weakened as the same governments embraced the concept of 'open skies', reflecting a "development of major importance for the airline industry: liberalization unfolding around the globe" (EVANS et al., 2003, p. 166). 
The liberalization and deregulation trend commenced in the late 1970's with the passing of the Airline Deregulation Act (1978). The European Union followed within ten years, phasing in three radical liberalization packages for the aviation sector in 1987, 1990 and 1993 (PENDER and SHARPLEY, 2005). Notably, as Pender and Sharpley (2005, p.38) suggest, these changes left the EU regulatory environment "even more liberal" than that of the USA. Most significantly the international airline environment was changed to a new 'mixed market' which included public, semi-public and private carriers - now in direct competition for market share.

Figure 1: Development of demand for Air Travel in the World

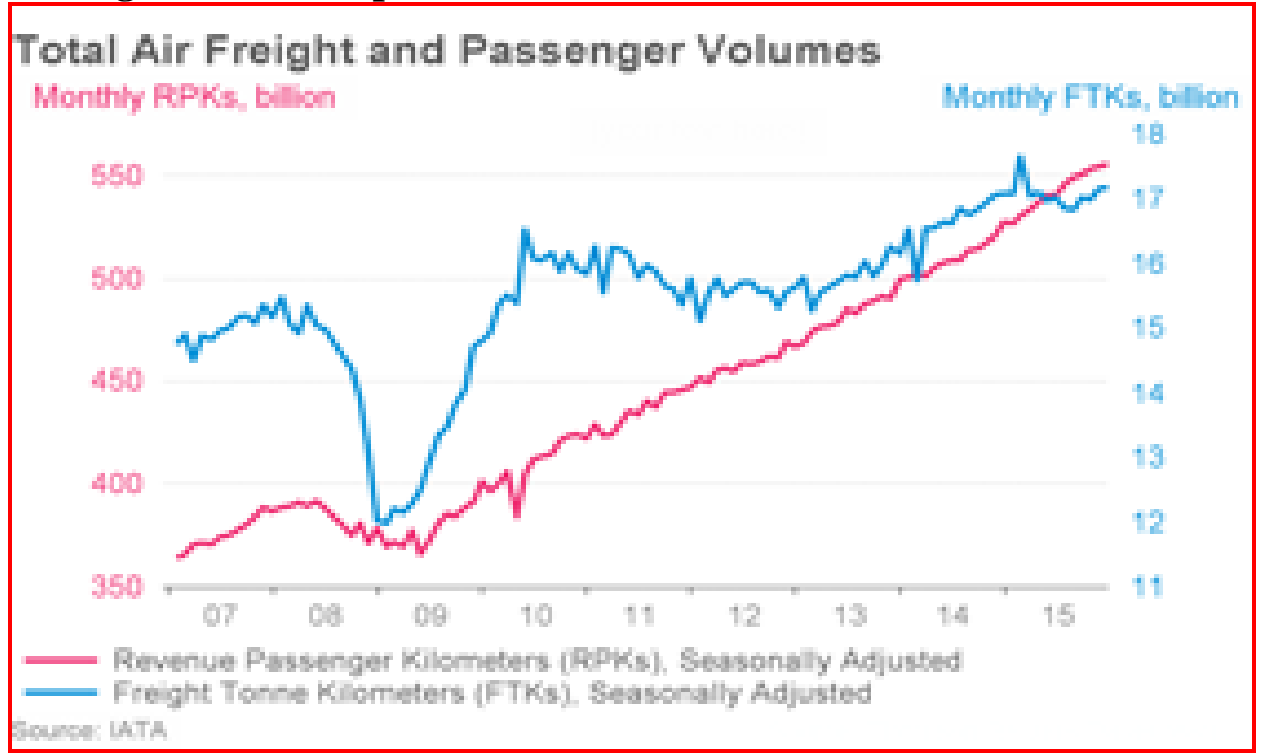

Source: International Air Transport Association - IATA (2016)

This new competition lead to the so called 'full service network carriers' (FSNCs) switching their operations from a 'point to point' system, to one of 'hub and spoke' (CENTO, 2009, p. 184 apud GABOR, 2010, p. 51), ${ }^{3}$ since as Gabor notes "prices became primarily demand-oriented and economies of scale got more and more important" (GABOR, 2010, p.51). In contrast, the LCCs took up the point to point system which allowed them, within the new liberalized environment, to "pick up the price-sensitive market share...[by]...offering cheaper tickets." (GABOR, 2010, p.51). ${ }^{4}$ As Gabor correctly notes, "first in North-America, then in Europe and now everywhere in the world", the dynamic growth rates of LCCs are among the "most important achievement of liberalization" (GABOR, 2010, p.51).

\footnotetext{
${ }^{3}$ See also WTO (2010, p.8).

${ }^{4}$ See also Gillen, Gados, (2008)
} 
It is necessary however to acknowledge that heavy regulation concerning airline ownership has not disappeared. Rather, it remains vigorously regulated. In the case of the USA, for example, airlines are still subject to 'substantial national ownership' and/or 'controlling interest' demands. This 'protectionist' measure clearly insulates from international competition, those national carriers servicing domestic and hemispheric routes. However, it does also reflect, the airlines industries perceived strategic significance to US authorities, a point acknowledged by Doganis (2001). Ironically as Evans et al. (2003, p.167) goes on to acutely point out, in the USA "most international of industries remains almost exclusively national in terms of ownership and control. ${ }^{\circ 5}$ Clearly, despite the radical liberalization of air travel regulations in recent decades, air transport remains firmly within the macro political environment of state power. Such ownership restrictions, present a keen counter point, to what has seemed at times a ubiquitous trend in market liberalization over the last 30 years. Particularly given that it's a position taken by the world's most powerful military and trading nation (albeit declining and relatively terms), in addition to, the most ardent and influential state advocate of international liberalization measures. Nevertheless, the liberalization trend in air passenger and cargo travel in recent decades has greatly contributed to the emergence and development of 'airline hubs' and 'collaborative' strategic alliances (WORLD TOURISM ORGANIZATION, 2002, p. 3).

\section{TOURISM MICRO TRENDS: RISE OF EUROPEAN LOW COST CARRIERS (LCCS)}

As the transport sector is, as Keith Debbage notes, the "key element" matching "tourist demand (origin) with tourist supply (destination)" (DEBBAGE, in PENDER \& SHARPLEY, 2005, p.30), the huge influence of Air transit deregulation in the US and Europe could be seen in both "airlines network structures and business policies", as operations became more "profit oriented due to the free market" (GABOR, 2010, p.51). While the European airline market has been progressively expanding since its emergence having "more than doubled in size since 1990", the most significant growth trends have been "almost entirely fueled by low-cost carriers".

\footnotetext{
${ }^{5}$ See also Doganis (2001). 
Figure 2: European market share of low-cost carriers

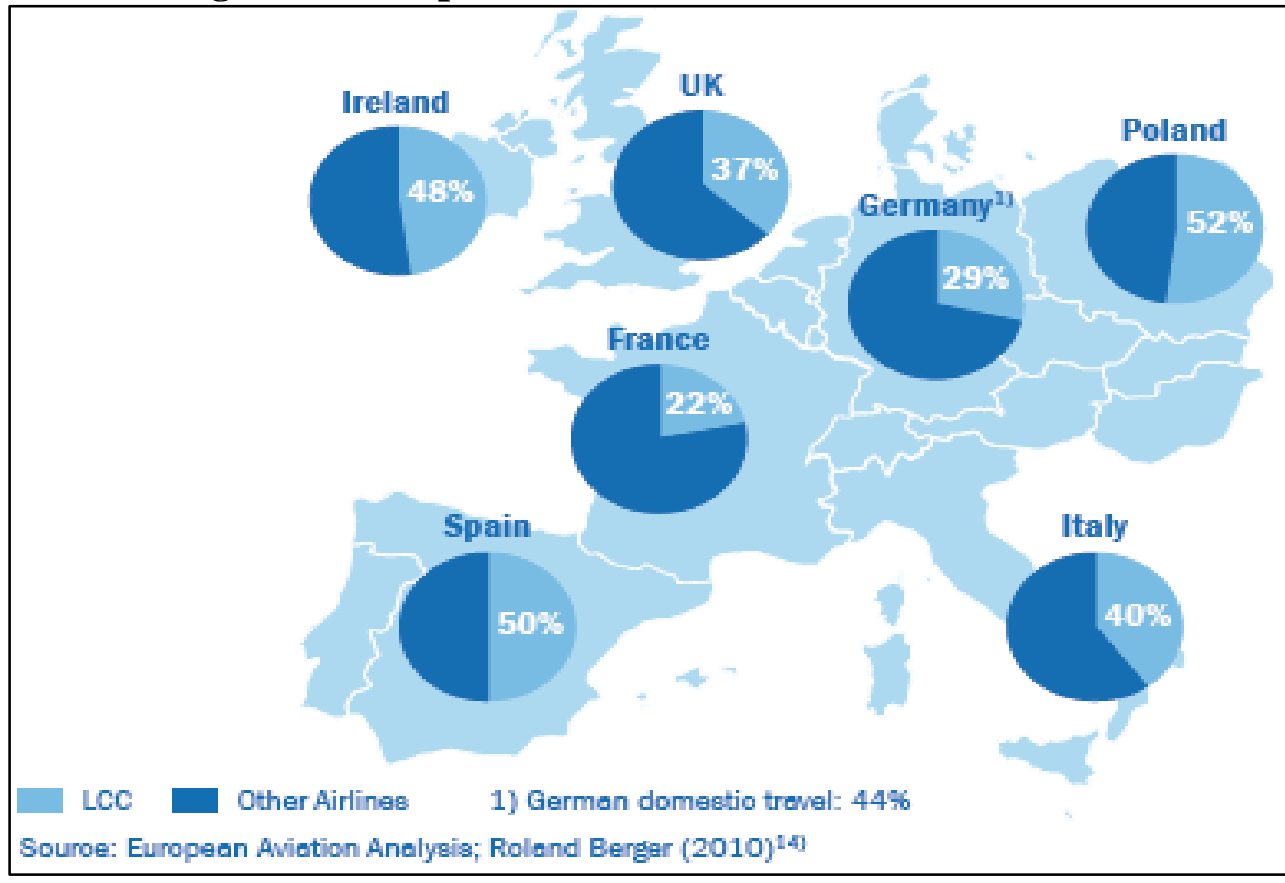

Source: Roland Berger Strategy Consultants, Zurich (2010, p.8).

Companies which are characteristically smaller, leaner and more 'flexible' than the traditional network carriers, helping them to "tap into almost every market within Europe" (BERGER, 2010, p. 3); some core elements of the LCC business model included: low unrestricted fares, high service frequency and point to point service with no interlining.

TABLE (A): European LCC network features

\begin{tabular}{|c|c|c|c|c|c|c|c|}
\hline LCC in 2004 & $\begin{array}{c}\text { Number of } \\
\text { Destinations }\end{array}$ & $\begin{array}{c}\text { Number } \\
\text { of } \\
\text { Routes }\end{array}$ & $\begin{array}{c}\text { Exclusive } \\
\text { Routes } \\
\text { \% }\end{array}$ & $\begin{array}{c}\text { LCC in July } \\
\mathbf{2 0 0 9}\end{array}$ & $\begin{array}{c}\text { Number of } \\
\text { Destinations }\end{array}$ & $\begin{array}{c}\text { Number } \\
\text { of } \\
\text { Routes }\end{array}$ & $\begin{array}{c}\text { Exclusive } \\
\text { Routes } \\
\text { \% }\end{array}$ \\
\hline Alpi Eagles & 9 & 22 & 27 & Aer Lingus & 59 & 88 & 69 \\
\hline Bmibaby & 24 & 78 & 59 & Blue Air & 34 & 45 & 87 \\
\hline Deutsche BA & 8 & 26 & 31 & Bmibaby & 29 & 63 & 51 \\
\hline EasyJet & 38 & 238 & 65 & EasyJet & 110 & 445 & 79 \\
\hline Flybe & 32 & 111 & 77 & Flybe & 56 & 162 & 90 \\
\hline Germania & 17 & 54 & 15 & Flyglobespan & 20 & 36 & 72 \\
\hline $\begin{array}{c}\text { Germanwing } \\
\text { S }\end{array}$ & 32 & 66 & 70 & Germanwings & 66 & 121 & 85 \\
\hline $\begin{array}{c}\text { Hapag-Lloyd } \\
\text { Express }\end{array}$ & 19 & 42 & 86 & Jet2 & 48 & 105 & 79 \\
\hline Intersky & 5 & 10 & 100 & Monarch & 19 & 49 & 41 \\
\hline $\begin{array}{c}\text { Jet2 } \\
\text { Monarch } \\
\text { Scheduled }\end{array}$ & 13 & 23 & 91 & Myair & 31 & 50 & 82 \\
\hline $\begin{array}{c}\text { MyTravel } \\
\text { Lite }\end{array}$ & 14 & 32 & 31 & Norwegian & 75 & 164 & 95 \\
\hline Norwegian & 21 & 46 & 60 & Ryanair & 145 & 818 & 93 \\
\hline Ryanair & 84 & 292 & 93 & Transavia & 68 & 96 & 91 \\
\hline Sky Europe & 9 & 16 & 88 & TUIfly & 70 & 272 & 94 \\
\hline
\end{tabular}




\begin{tabular}{|c|c|c|c|c|c|c|c|}
\hline $\begin{array}{c}\text { Skynet } \\
\text { Airlines }\end{array}$ & 4 & 6 & 67 & Vueling & 44 & 89 & 81 \\
\hline Sterling & 14 & 42 & 33 & Windjet & 29 & 46 & 93 \\
\hline $\begin{array}{c}\text { Virgin } \\
\text { Express }\end{array}$ & 15 & 30 & 23 & Wizzair & 52 & 143 & 88 \\
\hline
\end{tabular}

Source: Gabor, (2010: 57), adapted from Dobruszkes, (2009)

TABLE (B): The original low cost business model as initiated by Southwest Airlines

\begin{tabular}{|l|l|}
\hline Product Features \\
\hline 1. Fares/Network & Low, simple and unrestricted fares, high frequencies, point to point, no interlining \\
\hline 2. Distribution & Travel agents and call centers [today internet sales], ticketless \\
\hline 3. In-flight & $\begin{array}{l}\text { Single class, high density seating, no meals or free alcoholic drinks, snacks and light } \\
\text { beverages can be purchased, no seat assignment }\end{array}$ \\
\hline Operating Features & \multicolumn{2}{|l|}{ Single type, Boeing 737 types, high utilization, 11-12 hours/day } \\
\hline 1. Fleet & Secondary or uncongested, 20-30 minute turnarounds \\
\hline 2. Airport & Short, average 400 nautical miles \\
\hline 3. Sector length & Competitive wages, profit sharing, high productivity \\
\hline 4. Staff &
\end{tabular}

Source: Gabor, (2010: 52), adapted from Pate and Beaumont, (2006)

Indeed, since the emergence and strong market growth of LCCs in the 1990s, the "growth trend of established network carriers has stopped," their relative market share decreasing relationally.

TABLE (C): European low-cost supply spread (millions of seats)

\begin{tabular}{|l|c|c|c|c|}
\hline & \multicolumn{2}{|c|}{ January 2004 } & \multicolumn{2}{c|}{ January 2008 } \\
\hline West - West & 7,89 & $98 \%$ & 13,4 & $83 \%$ \\
\hline West - East & 0,14 & $2 \%$ & 2,13 & $13 \%$ \\
\hline East - East & 0,01 & $0 \%$ & 0,07 & $0 \%$ \\
\hline West - Other & 0,03 & $0 \%$ & 0,57 & $4 \%$ \\
\hline Total & 8,08 & $100 \%$ & 16,17 & $100 \%$ \\
\hline
\end{tabular}

Source: Gabor, (2010: 54), adapted from Dobruszkes, (2009)

TABLE (D): European low-cost geographical supply distribution (city-pairs)

\begin{tabular}{|l|l|l|l|l|l|l|}
\hline & \multicolumn{2}{|c|}{ January 2004 } & \multicolumn{2}{|c|}{ January 2008 } & \multicolumn{2}{c|}{ July 2009 } \\
\hline West - West & 512 & $94 \%$ & 964 & $72 \%$ & 1971 & $75 \%$ \\
\hline West - East & 21 & $4 \%$ & 285 & $21 \%$ & 399 & $15 \%$ \\
\hline East - East & 2 & $0 \%$ & 7 & $1 \%$ & 15 & $1 \%$ \\
\hline West - Other & 11 & $2 \%$ & 81 & $6 \%$ & 241 & $9 \%$ \\
\hline East - Other & & & & & 10 & $0 \%$ \\
\hline Total & 546 & $100 \%$ & 1336 & $100 \%$ & 2636 & $100 \%$ \\
\hline
\end{tabular}

Source: Gabor, (2010, p.54), adapted from Dobruszkes, (2009) 
In contrast, as industry specialists Roland Berger stated, the fledgling LCCs grew at "high double digit rates", increasing their collective market share from just " $5 \%$ in 2001 to $32 \%$ in 2008" (BERGER, 2010, p.7). Gabor (2010) demonstrates that through an analysis of LCCs routes and schedules, three clear trends emerge. Until 2008 the number of available seats doubled; there was a dramatic increase in destinations; with a concomitant increase in route supply (inc. new West-East routes).

Figure 3(a): European low-cost networks (July 2009)
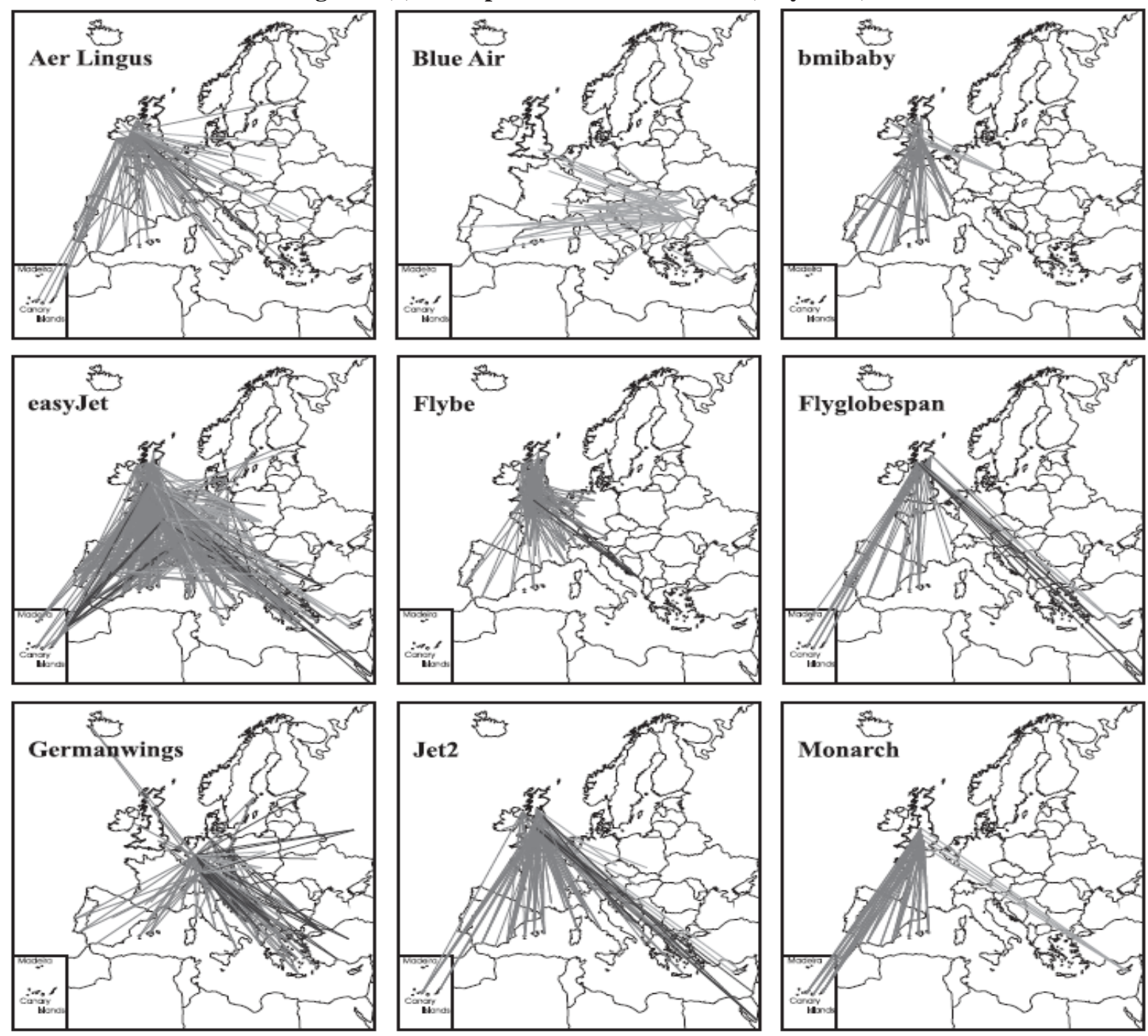

- West - West routes

West-East routes

- Others

Source: Gabor (2010, p.55) 
Figure 3(b): European low-cost networks (July 2009)
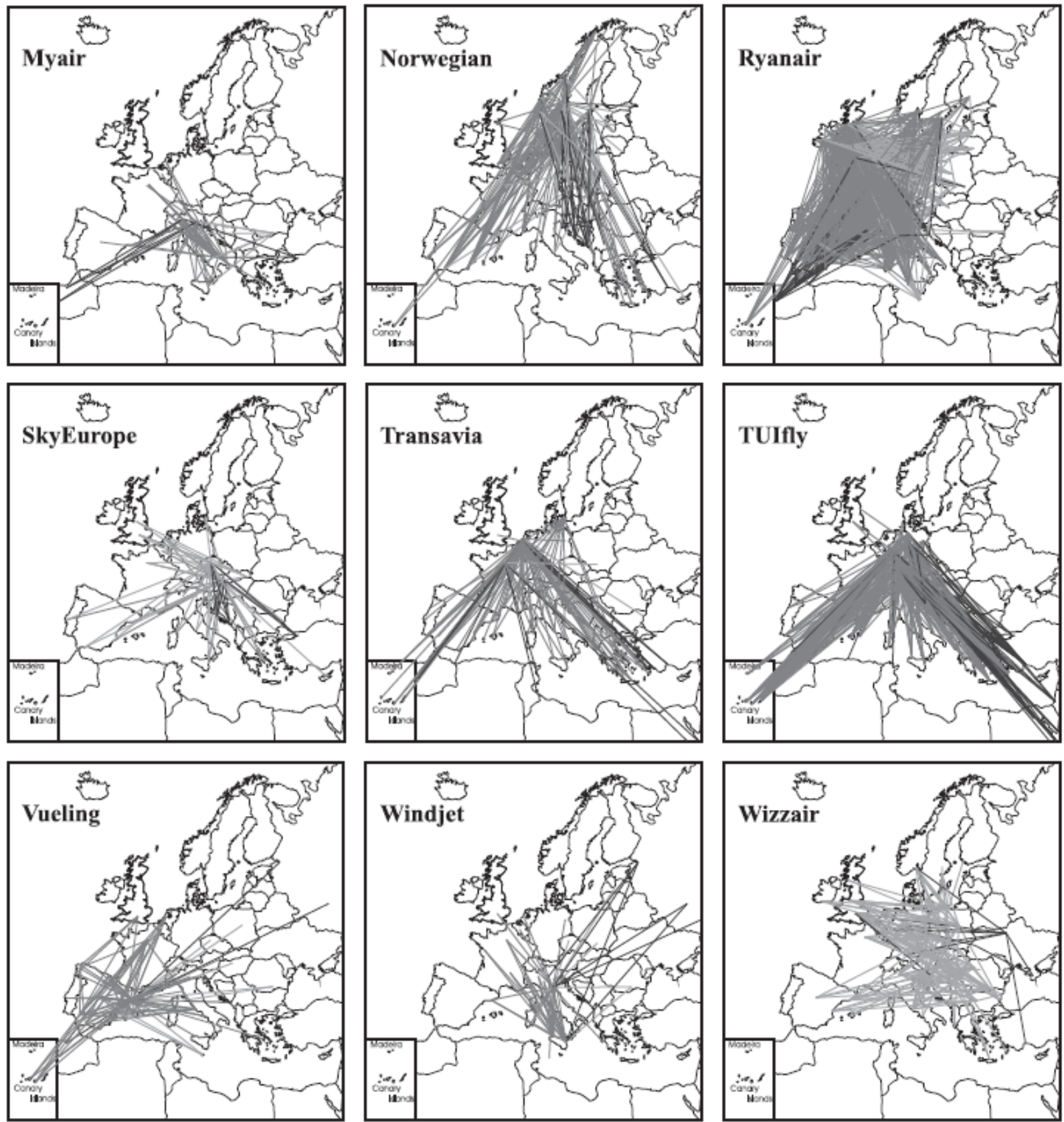

- West - West routes

- West-East routes

- Others

Source: Gabor, (2010, p.56) 
Dundas Gabor points to important additional catalysts in this respect.

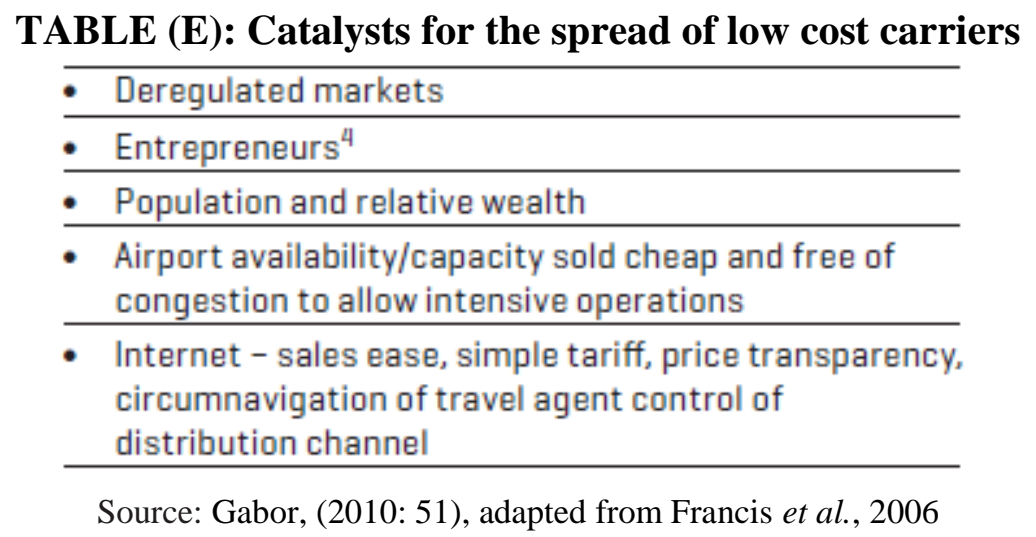

One key driver was the severe "downturn in the aviation sector between 2001 and 2003", driven by the 9/11 terror attacks, the war against Iraq and Afghanistan, as well as the SARS outbreaks. Together these and other influences helped fuel great reductions in passenger numbers, in addition to "the income(s) of FSNCs" (GABOR, 2010, p.53). Both legacy carriers and charter carriers responded by launching their own "low-cost" subsidiaries, more than a dozen new LCCs entering the market (DOGANIS 2006, apud GABOR, 2010).

Through this important growth driven restructuring of the market, three types of LCC network structure also emerged. Firstly, 'north-south' flows (e.g. Monarch, Transavia, Tui Fly), focused almost entirely on trips to the Mediterranean coasts (e.g. Ibiza, Palma de Mallorca, Crete). The airlines serving this market segment tending to be either subsidiaries of a larger FSNCs, like British Midland's subsidiary bmibaby, or they appear as 'hybrid' LCCs which are partly charter carriers (e.g. TUIfly), but also offer scheduled flights to popular holiday destinations (e.g. Monarch). Secondly 'west-east' flows by companies like Blue Air and Wizzair; with Wizzair for example, concentrating on high demand services between Polish and English cities (GABOR, 2010). Thirdly, 'mixed network structures' (e.g. Ryanair and EasyJet). Arguably these two 'low cost champions' Ryanair and easyJet have lead the European market through taking advantage of what Gabor describes as their "first starter position" in the LCC market - building up an "enormous route network". A point he illustrates by the fact that, these two hybrid champions operate "three times more routes" than their next largest competitor (TUIfly). This position was achieved by offering products/services to both leisure and business travelers. In addition to, both north-south and west-west connections, as well as, a growing number of west-east travel links (GABOR, 2010, p.56). 
The principal difference between the network strategies of these market leaders, has been not so much the service they offer (both offering ancillary service through partner companies in the supply chain), but rather their choice of airport use. Whereas Ryanair services focus around so called 'secondary airports' (e.g. Frankfurt Hann, Glasgow Prestwick), serving leisure costumers. In contrast, easyJet's operational network serves both secondary and primary airports (e.g. London Gatwick, Milano Malpensa), offering more connections for business travel markets focused around large and middle sized city centers (O’CONNELL, WILLIAMS, 2005, apud GABOR, 2010).

Gabor's network analysis helps to demonstrate the significant growth trend of LCCs in Europe. The innovative business model adopted by the LCCs, does not rely simply upon high ticket sales as the "primary source of profit". Rather, relying on other ancillary income streams such as: "surcharges, advertisements, car rental, credit card fees, travel insurances..." (GABOR, 2010, p.53). Additionally, LCCs operate with much lower crew expenses than FSNCs. In 2002 the European Cockpit Association reported that pilots working for LCCs receive around $28 \%$ less than pilots employed by FSNCs, while delivering around $25 \%$ more air time. Whereas the whole crew is expected to handle more operational tasks, such as "flight planning, cleaning the plane, checking fuel levels" and so on (DOBRUSZKES, 2006, apud GABOR, 2010, p.53). In a tourism sector where "controlling demand is as important as controlling costs and supplies" (GABOR, 2010, p.53). ${ }^{6}$

Despite the birth and expansion of low-cost airlines was in Europe, this process developed rapidly in other continents, even if in Africa and South America only partly or only in some countries. Following, some tables indicating the nations that have low cost companies in other continents beyond Europe.

TABLE (F): List of the main low cost airlines in North America

\begin{tabular}{|c|c|l|}
\hline $\begin{array}{c}\text { Countries } \\
\text { of North } \\
\text { America }\end{array}$ & Airlines & \multicolumn{1}{|c|}{ Destinations } \\
\hline Canada & Air Transat & $\begin{array}{l}\text { Flights within Canada and from Canada to the Caribbean, Europe and } \\
\text { the United States of America }\end{array}$ \\
\hline Canada & Sunwing Airlines & $\begin{array}{l}\text { Flights within Canada and from Canada to Mexico, Central America, } \\
\text { the Caribbean and the United States }\end{array}$ \\
\hline Canada & WestJet & $\begin{array}{l}\text { Flights within Canada and from Canada to the United States, Mexico } \\
\text { and the Caribbean }\end{array}$ \\
\hline USA & Allegiant Air & Flights within the United States and destinations near Canada \\
\hline USA & Frontier Airlines & $\begin{array}{l}\text { Flights from Denver to various destinations in the United States, } \\
\text { Mexico, Costa Rica, Jamaica, Dominican Republic and Canada }\end{array}$ \\
\hline
\end{tabular}

\footnotetext{
${ }^{6}$ See also Gillen, Gados, (2008).
} 


\begin{tabular}{|c|c|l|}
\hline USA & Alaska Air & $\begin{array}{l}\text { Flights within the United States and from the United States to Mexico, } \\
\text { Canada and Alaska }\end{array}$ \\
\hline USA & JetBlue Airways & $\begin{array}{l}\text { Flights within the USA and from the USA to the Caribbean, Bahamas, } \\
\text { Bermuda, Mexico, Colombia, Costa Rica and Peru }\end{array}$ \\
\hline USA & Republic Airlines & Flights within the USA and from the USA to Canada and the Bahamas \\
\hline USA & Southwest Airlines & $\begin{array}{l}\text { Flights within the USA and from the USA to Mexico, Costa Rica and } \\
\text { the Caribbean. It is considered the country's largest low-cost airline }\end{array}$ \\
\hline USA & Spirit Airlines & $\begin{array}{l}\text { Flights within the USA and from the USA to various destinations in the } \\
\text { Caribbean, Bahamas, Mexico, Central America, Peru and Colombia }\end{array}$ \\
\hline USA & $\begin{array}{c}\text { Sun Country } \\
\text { Airlines }\end{array}$ & $\begin{array}{l}\text { Flights within the United States and from the United States to the } \\
\text { Caribbean, Mexico, Costa Rica and Alaska }\end{array}$ \\
\hline USA & Virgin America & Flights within the USA and from USA to Mexico \\
\hline Mexico & Interjet & Flights within Mexico and to USA \\
\hline Mexico & Viva Aerobus & The cheapest flights in Mexico \\
\hline Mexico & Volaris & Flights within Mexico and to USA \\
\hline
\end{tabular}

Source: Adapted from Vowles, 2016

TABLE (G): List of the main low cost airlines in South America

\begin{tabular}{|c|c|l|}
\hline $\begin{array}{c}\text { Countries of } \\
\text { South America }\end{array}$ & Airlines & \multicolumn{1}{|c|}{ Destinations } \\
\hline Argentine & Sól línea aerea & $\begin{array}{l}\text { Flights within Argentine and from Argentine to the others destinations } \\
\text { in South America (Comodoro Rivadavia, Merlo, Punta del Este, } \\
\text { Rosario, San Luis, Santa Fe, Trelew and Villa Mercedes }\end{array}$ \\
\hline Argentine & $\begin{array}{c}\text { Aerolinas } \\
\text { Argentinas }\end{array}$ & $\begin{array}{l}\text { Flights within Argentine and from Argentine to the others international } \\
\text { destinations }\end{array}$ \\
\hline Brazil & Azul & $\begin{array}{l}\text { Flights within Brazil and also to destinations of USA (Orlando, Ft. } \\
\text { Lauderdale) }\end{array}$ \\
\hline Brazil & Gol & $\begin{array}{l}\text { Flights within Brazil and also to destinations of North and South } \\
\text { America }\end{array}$ \\
\hline Brazil & Passaredo & Flights to various destinations in Brazil \\
\hline Brazil & Sete & $\begin{array}{l}\text { Flights to various destinations in Brazil (Altamira, Araguaina, Belem, } \\
\text { Brasília, Goiania, Imperatriz, Maraba, Monte Dourado, Ourilandia, } \\
\text { Palmas, Redenção, São Luis and Teresina }\end{array}$ \\
\hline Chile & Sky Airlines & Flights within Chile and also to destinations of South America \\
\hline Colombia & $\begin{array}{c}\text { Avianca } \\
\text { Colombia }\end{array}$ & $\begin{array}{l}\text { Flights within Colombia and also to destinations of North and South } \\
\text { America and Europe }\end{array}$ \\
\hline Colombia & EasyFly & Flights to various destinations in Colombia \\
\hline Colombia & $\begin{array}{c}\text { Viva } \\
\text { Colombia }\end{array}$ & $\begin{array}{l}\text { Flights to various destinations in Colombia and also Panama, Lima and } \\
\text { Quito }\end{array}$ \\
\hline Peru & LC Peru & $\begin{array}{l}\text { Flights from Lima to Andahuaylas, Ayacucho, Cajamarca, Huanuco, } \\
\text { Huaraz and Tingo Maria }\end{array}$ \\
\hline Peru & Peruvian & $\begin{array}{l}\text { Flights to various destinations in Peru (Lima, Arequipa, Cusco, Iquitos } \\
\text { and Tacna) }\end{array}$ \\
\hline Start Peru & $\begin{array}{l}\text { Flights to various destinations in Peru (Lima, Arequipa, Cusco, Iquitos, } \\
\text { Talara, Tarapoto, Trujillo, Pucallpa, Juliaca, Puerto Maldonado) }\end{array}$ \\
\hline OnAL CIVIL AVIATION ORGANZATON (ICAO), 2017
\end{tabular}

Source: Adapted from INTERNATIONAL CIVIL AVIATION ORGANIZATION (ICAO), 2017

TABLE (H): List of the main low cost airlines in Africa

\begin{tabular}{|c|c|l|}
\hline $\begin{array}{c}\text { Countries } \\
\text { of Africa }\end{array}$ & Airlines & Destinations \\
\hline $\begin{array}{c}\text { South } \\
\text { Africa }\end{array}$ & FlySafair & Flights within the cities of Johannesburg, Cape Town and Port Elisabeth \\
\hline $\begin{array}{c}\text { South } \\
\text { Africa }\end{array}$ & Kulula & Flights within various destinations in South Africa \\
\hline South & Mango & Flights within various destinations in South Africa \\
\hline
\end{tabular}




\begin{tabular}{|c|c|l|}
\hline Africa & & \\
\hline Egypt & Air Arabia Egypt & Flights to various destinations in Africa, Middle East and Europe \\
\hline Kenya & Fly 540 & Flights within Kenya and also to South Sudan and Tanzania \\
\hline Kenya & Jambo Jet & Flights within the cities of Mombasa, Nairobi, Kisumu and Eldoret \\
\hline Morocco & Air Arabia Marroc & Flights from Morocco to various destinations in Europe \\
\hline Tanzania & FastJet & Flights from Tanzania to South Africa, Zimbabwe, Zambia and Uganda \\
\hline Zimbabwe & Fly Africa & Flights between Zimbabwe and South Africa \\
\hline
\end{tabular}

Source: Adapted from INTERNATIONAL CIVIL AVIATION ORGANIZATION (ICAO), 2017

\section{TABLE (I): List of the main low cost airlines in Oceania}

\begin{tabular}{|c|c|l|}
\hline $\begin{array}{c}\text { Countries } \\
\text { of } \\
\text { Oceania }\end{array}$ & \multicolumn{1}{|c|}{ Airlines } & \multicolumn{1}{|c|}{ Destinations } \\
\hline Australia & Jetstar & $\begin{array}{l}\text { Flights within different destinations in Australia and also to international } \\
\text { destinations as Cambodia, New Zealand, USA etc.. }\end{array}$ \\
\hline Australia & Qantas Domestic & $\begin{array}{l}\text { The company is not only low cost, since it also offers other options. } \\
\text { Flights within Australia and to various international destinations }\end{array}$ \\
\hline Australia & $\begin{array}{c}\text { REX (Regional } \\
\text { Express) }\end{array}$ & Flights within Australia and also to destinations such as South Africa \\
\hline Australia & Tiger Airways & Flights to various destinations within and outside Australia. \\
\hline Australia & Virgin Australia & $\begin{array}{l}\text { Flights to various destinations in Australia as well as international } \\
\text { flights. }\end{array}$ \\
\hline
\end{tabular}

Source: Adapted from INTERNATIONAL CIVIL AVIATION ORGANIZATION (ICAO), 2017

TABLE (L): List of the main low cost airlines in Asia

\begin{tabular}{|c|c|c|}
\hline $\begin{array}{l}\text { Countries } \\
\text { of Asia }\end{array}$ & Airlines & Destinations \\
\hline Cambodia & $\begin{array}{l}\text { Cambodia Angkor } \\
\text { Air }\end{array}$ & $\begin{array}{l}\text { Flights within Cambodia and to destinations in China, Thailand and } \\
\text { Vietnam }\end{array}$ \\
\hline China & 9Air & Flights between China, India and South Korea \\
\hline China & $\begin{array}{l}\text { Jetstar Hong } \\
\text { Kong }\end{array}$ & $\begin{array}{l}\text { It is based in Hong Kong and belongs to the Jetstar group, which is also } \\
\text { based in other countries. Flights to Japan, South Korea, Southeast Asia } \\
\text { and China }\end{array}$ \\
\hline China & Spring Airlines & Flights from Shanghai to over 30 destinations in Asia \\
\hline Singapore & FlyScoot & $\begin{array}{l}\text { Flights from Singapore to various destinations, including Sydney, Hong } \\
\text { Kong and Perth }\end{array}$ \\
\hline Singapore & Jetstar Asia & $\begin{array}{l}\text { It is based in Singapore and belongs to the Jetstar group, which is also } \\
\text { based in other countries. Flights to } 22 \text { destinations in Southeast Asia }\end{array}$ \\
\hline Singapore & Silk Air & Flights from Singapore to various national and international destinations \\
\hline Singapore & Tiger Airways & $\begin{array}{l}\text { Flights from Singapore to various destinations such as Australia, } \\
\text { Thailand, India and Vietnam }\end{array}$ \\
\hline Korea & Air Asia & Flights within Korea and international destinations \\
\hline Korea & Air Busan & $\begin{array}{l}\text { Flights within Korea (Busan, Gimpo and Jeju) and to Japan, China and } \\
\text { Southeast Asia }\end{array}$ \\
\hline Korea & Eastar Jet & $\begin{array}{l}\text { National flights (Gimpo, Kunsan, Jeju and Chongju) and international } \\
\text { flights }\end{array}$ \\
\hline Korea & Jeju Air & Flights to destinations within Korea and Japan \\
\hline Korea & Jin Air & Flights from Seoul to various regional and international destinations \\
\hline Korea & Sky Wings Air & Flights between Korea, Thailand, and Laos, or Vietnam and Cambodia \\
\hline Korea & T'wai Air & Flights from Korea to various destinations in Asia \\
\hline Philippines & Air Asia Zest & $\begin{array}{l}\text { Flights from Manila to other cities in the Philippines and also to } \\
\text { Shanghai, Busam and Seoul. Tickets are purchased on the Air Asia } \\
\text { website }\end{array}$ \\
\hline Philippines & Air Phill Express & Flights to various destinations in the Philippines and other countries \\
\hline Philippines & Cebu Pacific Air & $\begin{array}{l}\text { Flights within the Philippines and to various international destinations } \\
\text { such as Vietnam, Australia, Cambodia }\end{array}$ \\
\hline
\end{tabular}




\begin{tabular}{|c|c|c|}
\hline Philippines & $\begin{array}{l}\text { South East Asian } \\
\text { Airlines (Seair) }\end{array}$ & Flights within the Philippines and to Singapore and Hong Kong \\
\hline India & Air India Express & $\begin{array}{l}\text { Flights to } 13 \text { international destinations (Dubai, Sharjah, Abu Dhabi, Al } \\
\text { Ain, Muscat, Salalah, Singapore, KualaLumpur, Bahrain, Doha, Kuwait, } \\
\text { Columbo and Dhaka) }\end{array}$ \\
\hline India & $\begin{array}{l}\text { Air India } \\
\text { Regional }\end{array}$ & Flights to 31 international destinations, in addition to domestic flights \\
\hline India & Go Air & $\begin{array}{l}\text { Flights from Mumbai to Delhi, Ahmedabad, Cochin, Goa, Hyderabad, } \\
\text { Jaipur, Jammu and Srinagar }\end{array}$ \\
\hline India & Indigo Airlines & $\begin{array}{l}\text { Flights to more than } 20 \text { destinations within India and also international } \\
\text { flights like Singapore, Bangkok, Dubai, Muscat and Kathmandu }\end{array}$ \\
\hline India & Jet Lite Airlines & $\begin{array}{l}\text { Flights to various destinations within India, as well as international } \\
\text { flights such as Singapore, Colombo, Kuala Lumpur and Chicago }\end{array}$ \\
\hline India & SpiceJet & Flights to 18 destinations within India like Delhi, Varanasi and Goa \\
\hline Indonesia & Citilink & Flights within Indonesia \\
\hline Indonesia & Garuda Indonesia & $\begin{array}{l}\text { It is not considered 'low cost' but makes many promotions and in this } \\
\text { case the fares are very good. Flights to destinations within Indonesia and } \\
\text { international }\end{array}$ \\
\hline Indonesia & Lion Air & $\begin{array}{l}\text { Flights from Jakarta to domestic destinations and also to international } \\
\text { destinations such as Saudi Arabia and Singapore }\end{array}$ \\
\hline Indonesia & $\begin{array}{l}\text { Mandala Tiger } \\
\text { Air }\end{array}$ & $\begin{array}{l}\text { Flights to } 72 \text { destinations. Operates on four bases: Singapore, Australia, } \\
\text { Indonesia and the Philippines }\end{array}$ \\
\hline Japão & Amakusa Airlines & $\begin{array}{l}\text { It is the smallest company in Japan. It operates in the cities of Osaka, } \\
\text { Fukuoka, Kumamoto and Amakusa }\end{array}$ \\
\hline Japão & Air Asia & Flights within Japan and to international destinations \\
\hline Japão & Air Do & Flights to various destinations within Japan \\
\hline Japão & $\begin{array}{l}\text { Cebu Pacific } \\
\text { Airlines }\end{array}$ & Flights from Nagoya to Osaka \\
\hline Japão & Jeju Air & $\begin{array}{l}\text { Flights within Japan (Nagoya, Tokyo, Osaka, Okinawa and Fukuoka) } \\
\text { and also to Korea }\end{array}$ \\
\hline Japão & Jetstar & $\begin{array}{l}\text { It belongs to the Jetstar group, which is also based in other countries. } \\
\text { Flights within Japan }\end{array}$ \\
\hline Japão & Skinet Asia & Flights from Japan to various destinations in Asia \\
\hline Japão & Skymark & $\begin{array}{l}\text { Flights to various destinations within Japan such as Kobi, Nagasaki and } \\
\text { Sapporo }\end{array}$ \\
\hline Japão & Star Flyer & Domestic flights between cities in Japan \\
\hline Japão & Peach Airlines & Flights to 12 destinations in Japan and 7 other international destinations \\
\hline Laos & Lao Airlines & $\begin{array}{l}\text { Flights within Laos and destinations in Cambodia, China, Korea, } \\
\text { Singapore, Thailand and Vietnam }\end{array}$ \\
\hline Malasia & Air Asia & $\begin{array}{l}\text { Flights to various destinations within Malaysia and to other countries } \\
\text { (Thailand, China, Sri Lanka, Vietnam etc) }\end{array}$ \\
\hline Malasia & Firefly & $\begin{array}{l}\text { Flights within Malaysia and destinations in Indonesia, Singapore and } \\
\text { Thailand }\end{array}$ \\
\hline Malasia & Malindo Air & $\begin{array}{l}\text { Flights within Malaysia and destinations in Indonesia, India, } \\
\text { Bangladesh, Singapore, Thailand and Nepal }\end{array}$ \\
\hline Malasia & MASwings & Flights within Malaysia and still to Brunei and Indonesia \\
\hline Myanmar & $\begin{array}{l}\text { Golden Myanmar } \\
\text { Airlines }\end{array}$ & Flights to various destinations within Myanmar and to Singapore \\
\hline Sri Lanka & Air Asia & Flights from Capital Colombo to various destinations \\
\hline Sri Lanka & Mihin Lanka & $\begin{array}{l}\text { Flights from Colombo to various destinations, including the island of } \\
\text { Seychelles }\end{array}$ \\
\hline Thailand & Bangkok Air & $\begin{array}{l}\text { Flights within Thailand and to international destinations. Their prices } \\
\text { are not really cheap but the company operates in parts that others do not } \\
\text { operate }\end{array}$ \\
\hline Thailand & Nok Air & $\begin{array}{l}\text { Flights from Bangkok and Chiang Mai to various destinations in } \\
\text { Thailand and also to Laos, Myanmar and China }\end{array}$ \\
\hline Thailand & Orient Thai & Flights between Bangkok and Phuket and also to Hong Kong \\
\hline
\end{tabular}




\begin{tabular}{|c|c|l|}
\hline Vietnam & Jetstar Pacific & $\begin{array}{l}\text { It is based in Vietnam and belongs to the Jetstar group, which is also } \\
\text { based in other countries. Operates national and international destinations }\end{array}$ \\
\hline Vietnam & Viet Jet Air & Flights from Vietnam to various destinations in Asia \\
\hline Vietnam & Vietnam Airlines & $\begin{array}{l}\text { Flights within Vietnam and to international destinations, including the } \\
\text { United States and Europe }\end{array}$ \\
\hline Middle East & Air Arabia & $\begin{array}{l}\text { Flights to various destinations in the Middle East and also to various } \\
\text { international destinations }\end{array}$ \\
\hline Middle East & Fly Dubai & Flights to 26 destinations (Amman, Alexandria, Istanbul, Kuwait, etc) \\
\hline Middle East & Flynas & $\begin{array}{l}\text { Flights within Saudi Arabia and to diverse destinations like Dubai, } \\
\text { Antakya-Hatay and Khartoum. Operates in partnership with Etihad, } \\
\text { flying to 17 cities in 11 different countries }\end{array}$ \\
\hline Middle East & Jazeera Airways & Flights to 19 destinations in 11 different countries \\
\hline
\end{tabular}

Source: Adapted from INTERNATIONAL CIVIL AVIATION ORGANIZATION (ICAO), 2017

In conclusion, it can be argued that the "LCCs took advantage of the market segment neglected by FSNCs" (GABOR, 2010, p.57), creating new demand streams unexploited or overlooked by the legacy carriers. Also through dynamic innovations in product and service within the airline industry like yield management, ticketless internet bookings and check in. In a dynamic trend, rapidly increasing their market share in relation to the other traditional carriers.

\section{STRATEGIC PLANNING AND DEVELOPMENT IN EUROPEAN TOURISM OPERATIONS AT THE BEGINNING OF THE THIRD MILLENNIUM}

In this section we review a number of business development strategies influential in tourism management, starting by considering elements of Ansoff's matrix, a classic model for strategic planning.

Figure 4: The Ansoff matrix (growth vector components)

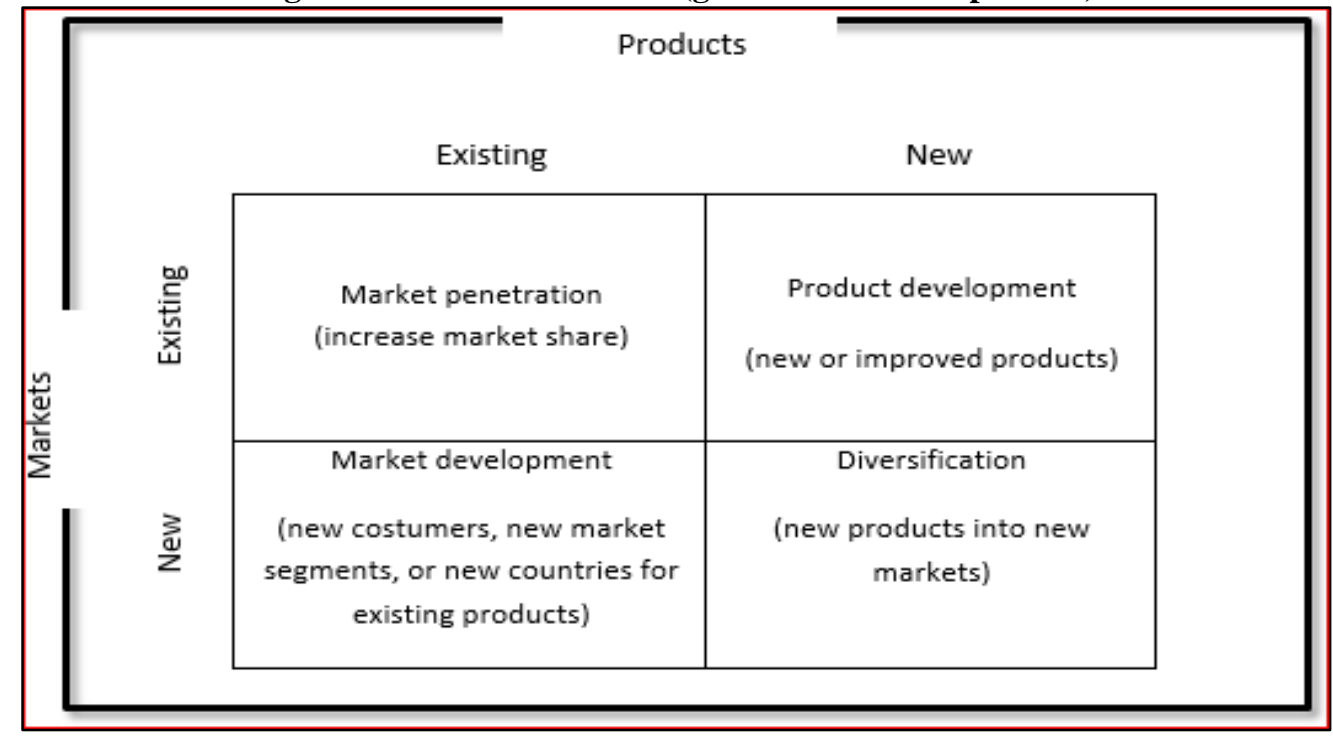

Source: Evans et al., (2003, p.229), adapted from Ansoff, I. (1987) 
The first strategy of development is market penetration (increased market share, e.g. Travelodge's expansion via franchising in UK). This model is generally most applicable when growth potential remains good in core market segments, or the company finds itself unable penetrate new markets (EVANS et al., 2003). Secondly, market development (new clients, sectors or geographies for existing products, e.g. Holidaybreak plc's development from Eurocamp). A key factor in repositioning existing products is the 'transferability' of those products and services to new segments and/or markets. Notably however, as companies enter new markets of which they may have limited knowledge - the risk of costly failures increase (EVANS et al., 2003). Thirdly, product development (new or improved products for existing markets e.g. Club Med World). The principle intention of product development is, to increase 'market share' among existing consumers and markets of which the company is familiar. A strategic direction most suited to firm's already holding relatively high market share (EVANS et al., 2003). However, with the advent of ever decreasing 'product life cycles', product development is arguably of particular importance, representing a critical element in the strategic development of tourism operations. Additionally this method presents other risks, especially considering new products can often fail. Given this almost continuous need for product development a critical trend towards diversification (new products or services into new markets, (e.g. First Choice plc) has taken hold (EVANS et al., 2003). Diversification consists in two main types. First: unrelated diversification entails the entry into new markets and products segments of which the company has little or no previous experience.

A good example of unrelated diversification in the tourism phenomenon is the case of Tui AG, one of the most important integrated tourism conglomerates. Tui AG group includes the German-based TUI Travel, as well as the UK based Thomson Travel Group, together operating in no less than 15 national European markets. This market leader was originally a Mining, Iron and Steel Company, formed by the Prussia state in 1923, and was called Preussag. Preussag left its core business to concentrate upon tourism related activities (EVANS et al., 2003). On the other hand, related (or concentric) diversification entails seeking to extend into new segments of markets currently being served. This having the advantage of reducing the risks associated with endeavors in unrelated spheres. In essence, this requires a process of either 'forward or backward' vertical diversification along a company's current supply chain. 


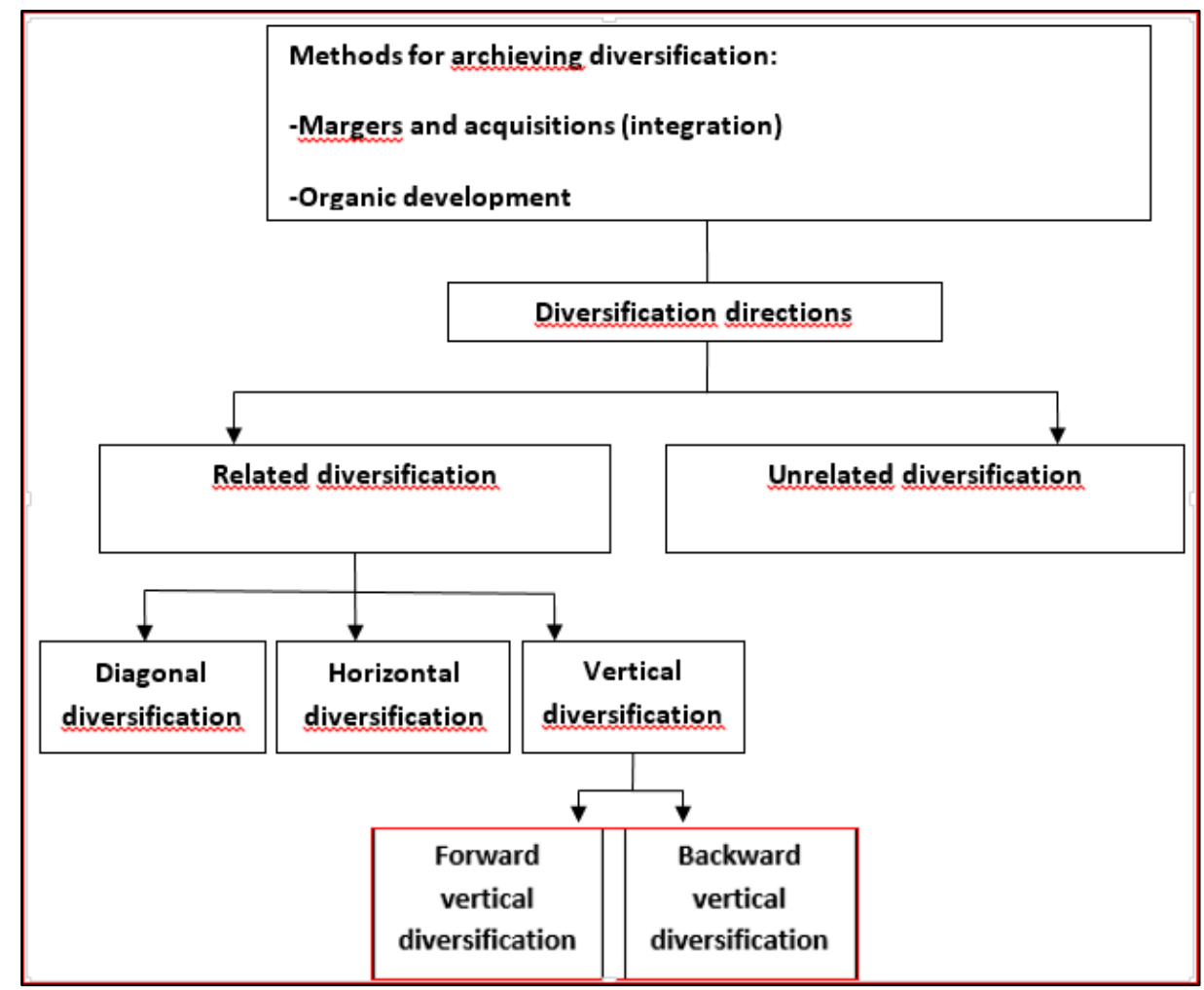

Source: Evans et al., (2003, p.233)

Figure 6: Patterns of related diversification

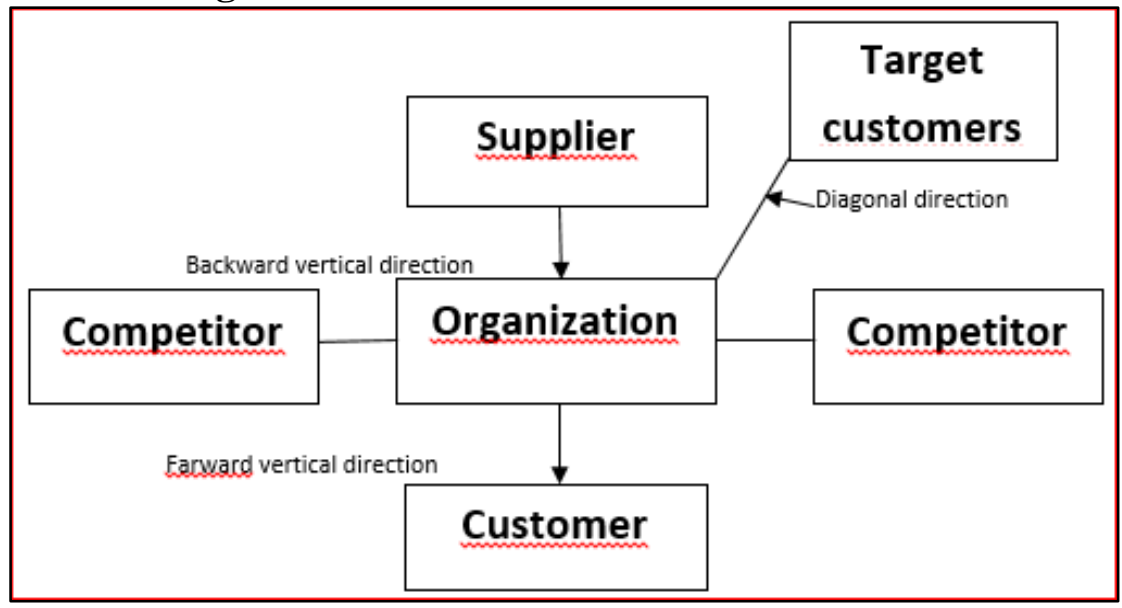

Source: Evans et al., (2003, p.234)

To gain new customers from companies already serving its own related clients and customers. For example, a tour operator (who has accommodation and an airline fleet), which adds a new distribution network to its current activities (e.g. an internet booking platform and/or a travel agency chain) is extending in a 'backward vertical' direction of its 'value chain' (EVANS et al., 2003, p. 223-224). If in contrast, a car hire business is added at the destination, a forward diversification is achieved. A good example of related diversification is the First Choice plc travel organization, encompassing both mainstream and niche tour 
companies, travel agencies as well as aviation subsidiaries. First Choice's successful diversification process has been achieved through both horizontal and vertical pathways. It accentuates the diversification trends in the travel industry in recent years, and has done so, in this case, mostly via the acquisition of related companies (EVANS et al., 2003). In contrast, organizations might pursue a process of 'horizontal diversification'. An example of this would be a strategic airline alliance. Another, a hotel company collaborating with others (e.g. roomkey.com), or by taking over another hotelier in order to gain entry to complementary or competing markets (EVANS et al., 2003). Both diversification directions contain there inherent advantages and risks and may be pursued simultaneously by organizations with the requisite management skill and resource base. Nevertheless, the diversification trend is clear, with many market leading tourism companies successfully applying this strategic model in order to grow their businesses. Finally, an important fourth model of related diversification is diagonal diversification. This is most widespread in service related commerce, relying upon the use of common "information-utilizing technology" (e.g. credit cards, insurance, currency exchange) in order to improve market intelligence and "target a group of customers with a closely related set of products" (EVANS et al., 2003, p.236).

Figure 7: Diagonal diversification map

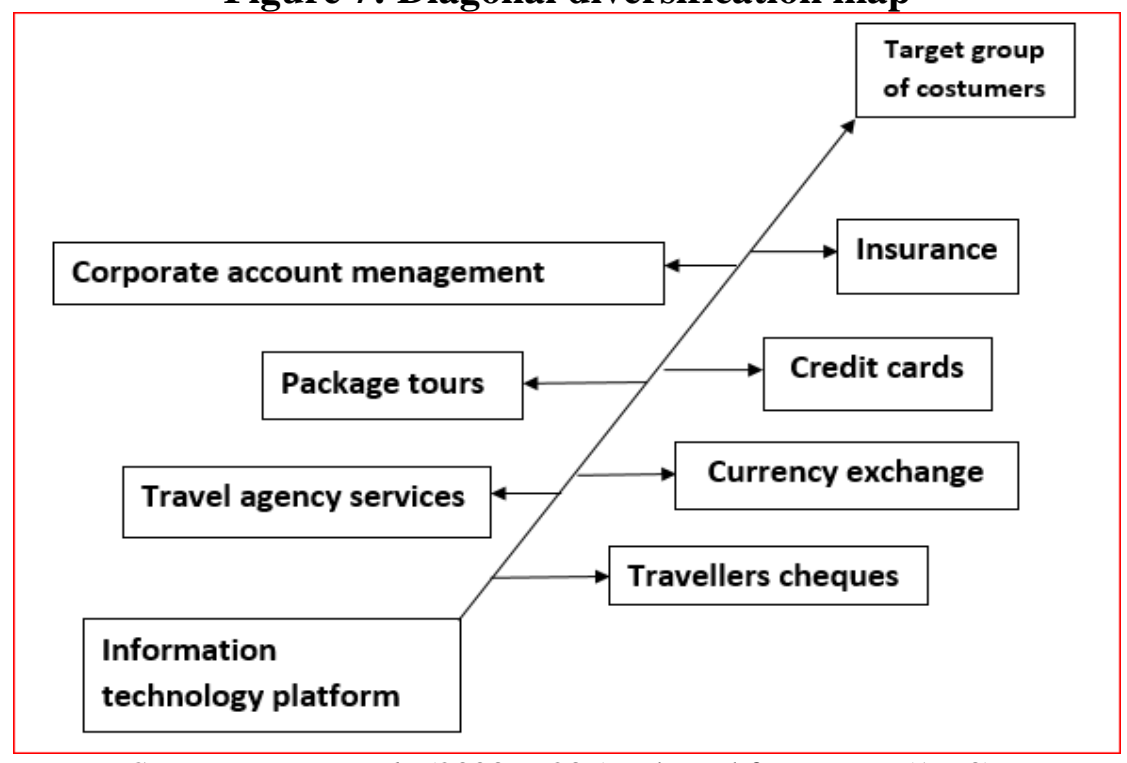

Source: Evans et al., (2003, p.236), adapted from Poon (1993).

The strategic mix of these directions argues Evans et al., will depend in part upon companies 'core competences' (either alone or in conjunction with partner organizations), and their accessible 'resource base', along with the 'levels of risk' organizations are willing to bear in order to grow. At the low end of the risk continuum, reside market penetration 
followed by product development, while at the higher risk end resides structural diversification (EVANS et al., 2003), where ironically the greatest potential profits lie.

\section{COLLABORATIVE TRENDS AMONG TOURISM SUPPLIERS}

This trend has arguably been driven by a growing realization that achieving competitive advantage, increased profits, and acceptable levels of growth within integrated international markets, can only be achieved through entry into collaborative partnerships and network configurations. Christopher et al. suggest that the fruits of globalized 'network competition', will increasingly accrue to organizations best able to "structure, coordinate and manage relationships" with their collaborative network partners (CHRISTOPHER, PAYNE, and BALLANTYNE, 2002 apud THEOBALD, 2005, p. 52). A number of important tendencies have emerged in tourism sectors, we might refer to as alternative development strategies. A huge trend has emerged surrounding strategic alliances in the travel industry. Horizontal inter-firm relationships where common strategic objectives are pursued (EVANS et al., 2003). Although the growth trend of strategic interlinking in tourism has flattened out somewhat in recent years, arguably this significant trend is here to stay. In fact, from the 1980s until the early 1990s strategic alliance formation within the global travel industry increased exponentially, creating the basic architectures of today's interlinked tourism business networks. Remarkable, then as now, a majority of the worlds "major airline, hotel and car rental firms were linked by a web of cross-shareholdings, joint ventures, and joint sales and service arrangements" (EVANS et al., 2003, p. 252). ${ }^{7}$ In the world of hotels and tour operators, alliance behaviors have also been prevalent. The Radisson Hotel Group, for example, has based in part, its international strategy, on "strategic alliances with local hotel groups around the world". Nevertheless, instances of strategic alliances formation among hotel companies are "less common as the preferred strategic method" (EVANS et al., 2003, p. 252). In an illustrative case of 'strategic alliance instability' is that of MyTravel and Carnival Cruises. In April 1996 they acquired 29.5\% of rival operator Airtours. The alliance was terminated soon after in 2001. The majority of international strategic alliances are inherently unstable organizational structures, with discouragingly high failure rates (BEAMISH and INKPEN, 1995 apud EVANS et al., 2003). Despite the seeming popularity of travel related strategic alliances they are inherently unstable organizations. As it turns out, they are

\footnotetext{
${ }^{7}$ See also Dev et al. (1996) 
frequently the lone viable mechanism of "market entry", where "regulatory and other barriers to entry effectively block other...entry modes" (e.g. substantial shareholding, full takeover) (EVANS et al., 2003, p. 254). Companies chose alliances with some reluctance, but do so in response to powerful market forces in an increasingly globalized world, where economies of scale and scope - rule the day.

\section{MARKETING TRENDS IN BUSINESS AND TOURISM: NEW PERSPECTIVES AND PRACTICES}

\section{Marketing 3.0}

An important trend driven by the use new wave digital technologies, is impacting both the marketing strategies of suppliers as well as consumers of tourism. This wave consists of three major forces: cheap computers mobile communication devices, as well as, increasing access to low-cost open internet sources/services. Today's consumers are becoming increasingly well informed about competing products in the market, easily comparing rival offerings simultaneously (KOTLER et al., 2010). It is a situation where product value and design, is ever more being defined by the savvy consumer, who can choose from a wide range of "functional characteristics and alternatives" (KOTLER et al., 2010, p.4). Consumers proposes Kotler et al., are no longer best regarded as "passive targets" of marketing promotions, but rather, should be viewed by management and marketing teams, as active participants or at times as 'co-creators' (sic) (KOTLER et al., 2010). Kotler et al., argue that great changes are occurring in the relationships between product/services, suppliers and consumers. The consumer society has been moving from the "one to many" transactions of the marketing 1.0 era (e.g. early to mid- $20^{\text {th }}$ century), to more directed "one to one" relational transactions (e.g. late $20^{\text {th }}$ century) of marketing 2.0. Lastly, marketing 3.0 (globalization and integration) where consumers and suppliers are ever more engaged in "many to many" collaborative interactions (KOTLER et al., 2010, p.63).

TABLE (M): Comparison of Marketing 1.0, 2.0 and 3.0

\begin{tabular}{|l|l|l|l|}
\hline & $\begin{array}{l}\text { Marketing 1.0 } \\
\text { Product-centric }\end{array}$ & $\begin{array}{l}\text { Marketing 2.0 } \\
\text { Consumer-oriented }\end{array}$ & $\begin{array}{l}\text { Marketing 3.0 } \\
\text { Values-driven }\end{array}$ \\
\hline Objective & Sell products & $\begin{array}{l}\text { Satisfy and retain the } \\
\text { consumers }\end{array}$ & $\begin{array}{l}\text { Make the world a } \\
\text { better place }\end{array}$ \\
\hline Enabling forces & Industrial Revolution & $\begin{array}{l}\text { Information } \\
\text { technology }\end{array}$ & New wave technology \\
\hline How companies see & Mass buyers with & Smarter consumer & Whole human with \\
\hline
\end{tabular}




\begin{tabular}{|l|l|l|l|}
\hline the market & physical needs & with mind and heart & mind, heart, and spirit \\
\hline $\begin{array}{l}\text { Key marketing } \\
\text { concept }\end{array}$ & Product development & Differentiation & Values \\
\hline $\begin{array}{l}\text { Company marketing } \\
\text { guidelines }\end{array}$ & Product specification & $\begin{array}{l}\text { Corporate and } \\
\text { product positioning }\end{array}$ & $\begin{array}{l}\text { Corporate mission, } \\
\text { vision, and values }\end{array}$ \\
\hline Value propositions & Functional & $\begin{array}{l}\text { Functional and } \\
\text { emotional }\end{array}$ & $\begin{array}{l}\text { Functional, emotional, } \\
\text { and spiritual }\end{array}$ \\
\hline $\begin{array}{l}\text { Interaction with } \\
\text { consumers }\end{array}$ & $\begin{array}{l}\text { One-to-many } \\
\text { transaction }\end{array}$ & $\begin{array}{l}\text { One-to-one } \\
\text { relationship }\end{array}$ & $\begin{array}{l}\text { Many-to-many } \\
\text { collaboration }\end{array}$ \\
\hline
\end{tabular}

Source: Gabor, (2010, p.54) ; Kotler et al., (2010, p.6)

As new wave technologies increasingly link people from across the globe, streams of news, ideas, and entertainment is both being created, as well as, consume by them (KOTLER et al., 2010), within a "nexus of collaborative, cultural, and spiritual marketing" interactions (KOTLER et al., 2010, p.5).

\section{Social media trends and tourism}

New wave technology is critically implicated in the rise of social media, while simultaneously being driven by it. Kotler et al., usefully dissect social media in two broad groupings. Firstly, expressive social media (internet blogs and social networking sites like Facebook, Myspace, Twitter; Flickr and YouTube). Secondly, collaborative social media (Wikipedia, Rotten Tomatoes etc.). Collaborative users are teaching, learning, sharing their activities, experiences and emotional views; all of which can have important consequences for product development and marketing departments (KOTLER et al., 2010).

The need to monitor and engage the consumer on multiple platforms, arguably, has never been greater. Not least given the fact that some bloggers/users may publish negative commentaries on companies' products and services. Comments that must be countered by company statements, or better, the views of a satisfied or supportive consumer/collaborator (KOTLER et al., 2010). For example, the so called 'viral marketing' trend, where "criticism can spread rapidly around the world (e.g. Twitter), is a case in point. Kotler at al., plausibly suggest, that because of the low-cost and bias-free nature of social media, it will become "the future for marketing communications" (KOTLER et al., 2010, p.9). The influence and budgets of corporate advertising in "shaping buying behavior" consequently diminishing (KOTLER et al., 2010, p.8). 
Prahalad and Krishnan (2008, apud KOTLER et al., 2010, p.63) argue accordingly, companies must understand that within these new networks, the 3.0 consumers' role is not simply one of promoting brands, but instead can be "extended to selling them."

\section{Consumer trust systems, communitization and co-creation}

Moreover, marketing visions are changing in reaction to a shift in 'consumer trust systems', from a "vertical mode to the more horizontal model of today". In these new environments consumers congregate in their own collaborative communities, "co-creating" their "own products and experiences." A sort of emerging 'communitization' process (KOTLER et al., 2010), where key community 'characters' lead choice making and value formation (KOTLER et al., 2010). Following Seth Godin, Kotler et al. argue, that modern consumers do not want to be connected to companies, but rather, "to other consumers" (KOTLER et al., 2010, p.33), in pools, webs, or hubs (FOURNIER and LEE, 2009, apud KOTLER et al., 2010), reflecting shared perspectives, tastes and values. Arguably these trends and their effects within the global market will have a decisive effect upon future marketing in tourism and beyond.

\section{CONCLUSION}

This paper has sought to discuss and contextualize a number of important trends associated with international tourism operation. In conclusion it may be stated that sociodemographic changes like population growth, greater life expectancy, changes in family structure and increased urbanism will present great opportunities and challenges for international travel operators. Most notable in this mix is perhaps the 'rise of the east'. Clearly, political liberalization has helped to revolutionize international travel, but significantly intense regulation does remain in many areas. Both trends are likely to continue. Our micro analysis of the airline sector has shown, that while low cost airlines have risen fast in the last decades, they have done so at the expense of the larger network carriers. This trend toward international budget airline travel will arguably develop strongly, including in new regions.

In terms of strategic planning and product development, the trend toward diversification and the seeking out of alternative 'asset light' business growth models also looks set to continue. Collaborative options like alliance, franchising and shared acquisitions 
will continue to be prevalent. New wave technological platforms are becoming ever more powerful.

In this redrawing of the marketing environment: collaborative and interactive platforms will become more important for companies seeking to keep existing customers and gain new ones.

\section{BIBLIOGRAPHY}

BEAMISH, P.W. and INKPEN, A.C. Keeping International Joint Ventures Stable and Profitable. Long Range Planning, Volume 28 (3), 26-36, 1995.

BERGER, R. Future Scenarios for the EU Airline Industry, Zurich: Center for Scenario Planning, 2010.

CENTO, A. The Airline Industry - Challenges in the 21st Century, Heidelberg: PhysicaVerlag, 2009.

DOBRUSZKES, F. An analysis of European low-cost airlines and their networks, Journal of Transport Geography, Volume 14, 249-264, 2006.

EVANS, N.; CAMPBELL, D.; STONEHOUSE, G. Strategic Management for Travel \& Tourism. Oxford: Butterworth-Heineman, 2003.

DEV, C.S.; KLEIN, S. and FISHER, R.A. A Market-based Approach for Partner Selection in Marketing Alliances. Journal of Travel Research, 11-17, Summer 1996.

DOGANIS, R. The Airline Business in the 21st Century. London: Routledge, 2001.

FOURNIER, S and LEE, L. Getting Brand Communities Right, Harvard Business Review, April 2009.

GABOR, D. Low-cost Airlines in Europe: Network Structures After the Enlargement of the European Union, Geographica Pannonica, Volume 14, Issue 2, 49-58, June 2010.

GILLEN, D.; GADOS, A. Airlines within airlines: Assessing the vulnerabilities of mixing business models. Research in Transport Economics 24, 25-35, 2008.

GODIN, S Tribes: We Need You to Lead Us. New York: Portfolio, 2008.

KOTLER, P.; KARTAJAYA, H. and SETIAWAN, I. Marketing 3.0, New Jersey: John Wiley, 2010.

INTERNATIONAL AIR TRANSPORT ASSOCIATION - (IATA). Demand for Air Travel in 2015 Surges to Strongest Result in Five Years. IATA Press Release No. 4. Available in http://www.iata.org/pressroom/pr/Pages/2016-02-04-01.aspx. Consulted on February 7, 2018, 2016. 
INTERNATIONAL CIVIL AVIATION ORGANIZATION (ICAO). List of low-cost carriers (LCCs) based on ICAO definition. ICAO DATA+, available on https://www.icao.int/sustainability/Documents/LCC-List.pdf , 13 June 2017.

MASON, P. Social Change and the Growth of Tourism. Oxford: Butterworth-Heineman, 2003.

O'CONNELL, J.F.; WILLIAMS, G. Passengers' perceptions of low cost airlines and full service carriers: A case study involving Ryanair, Aer Lingus, Air Asia and Malaysia Airlines. Journal of Air Transport Management, Volume 11, 259-272, 2005.

PENDER \& SHARPLEY, The Management of Tourism. London: Sage, 2005.

PRAHALAD, C.K. and KRISHNAN, M.S. The New Age of Innovation: Driving Cocreated Value through Global Networks. New York: McGraw-Hill, 2008.

RYAN C. and TRAUER, B., Aging populations: trends and the emergence of the nomad tourist, in Theobald, W. F. [Ed.]. Global Tourism (3rd Ed.), London: Elsevier, 510-528, 2005.

SAMPSON, A. Empires of the Sky: The Politics, Contests and Cartels of World Airlines. London: Hodder and Stoughton, 1984.

THEOBALD, W. Global Tourism (3rd Ed.). London: Elsevier, 2005.

VOWLES, T. M.; LÜCK, M. "Low Cost Carriers in the USA and Canada" in GROSS, S.; LÜCK, M. The Low Cost Carrier Worldwide. NewYork: Routledge, 2016.

WILLMOTT, P. and Young, M. The Symmetrical Family: Study of Work and Leisure in the London Region. London: Pelican, 1975.

WORLD TOURISM ORGANIZATION, Tourism in the Age of Alliances, Mergers and Acquisitions, Madrid: World Trade Organization, 2002.

WORLD TOURISM ORGANIZATION and EUROPEAN TRAVEL COMMISSION, Demographic Changes \& Tourism. Madrid: World Trade Organization, 2010.

YEOMAN, I. Tomorrow's Tourist - Scenarios \& Trends. Oxford: Elsevier, 2008.

Recebido em Novembro de 2017

Aprovado em Maio de 2018

Publicado em Julho de 2018 